\title{
Agroforestry and the Improvement of Soil Fertility: A View from Amazonia
}

\author{
Rachel C. Pinho, ${ }^{1}$ Robert P. Miller, ${ }^{2}$ and Sonia S. Alfaia ${ }^{1}$ \\ ${ }^{1}$ National Institute for Research in Amazon, INPA/CPCA, Agrarian Sciences Research Center, Avenue André Araújo, \\ 69038-000 Manaus, AM, Brazil \\ ${ }^{2}$ United Nations Development Program, (PNUD), Cj SHIS QI 25 Cj 03 C, 71640-220 Brasília, DF, Brazil \\ Correspondence should be addressed to Rachel C. Pinho, rachel.pinho@gmail.com
}

Received 16 October 2011; Revised 28 January 2012; Accepted 28 January 2012

Academic Editor: Robert L. Bradley

Copyright (๑) 2012 Rachel C. Pinho et al. This is an open access article distributed under the Creative Commons Attribution License, which permits unrestricted use, distribution, and reproduction in any medium, provided the original work is properly cited.

\begin{abstract}
This paper discusses the effects of trees on soil fertility, with a focus on agricultural systems in Amazonia. Relevant literature concerning the effects of trees on soil physical and chemical properties in tropical, subtropical, and temperate regions is reviewed, covering both natural ecosystems and agroecosystems. Soil carbon, in the form of organic matter, is considered as an indicator of biological activity as well as in relation to policy issues such as carbon sequestration and climate change. In the case of tropical soils and Amazonia, information on the effects of trees on soils is discussed in the context of traditional agriculture systems, as well as in regard to the development of more sustainable agricultural alternatives for the region. Lastly, attention is given to a case study in the savanna region of Roraima, northern Brazil, where a chronosequence of indigenous homegarden agroforestry systems showed clear effects of management practices involving trees on soil fertility. The use of diverse tree species and other practices employed in agroforestry systems can represent alternative forms of increasing soil fertility and maintaining agricultural production, with important practical applications for the sustainability of tropical agriculture.
\end{abstract}

\section{Introduction}

According to a study by the World Agroforestry Centre, ICRAF, $43 \%$ of the planet's agricultural lands (more than a billion hectares) has more than $10 \%$ tree cover [1]. A lesser but still significant area of agricultural land, 160 million hectares, has more than 50\% tree cover. The potential of trees to bring improvements in nutrition, income, housing, health, energy needs, and environmental sustainability in the agricultural landscape has guided ICRAF's mission, with the presence of trees being the principal component of an "evergreen agriculture" [2]. Within the array of benefits brought by trees, an important element is the positive effect of trees on soil properties and consequently benefits for crops. This paper explores current knowledge as to this relation between trees and soil, based on agroforestry systems research, as well as studies innon-agricultural or natural environments that demonstrate effects of trees on soil. Although we consider information from various ecosystems and biomes, the focus will be on Amazonia, where the authors have most of their experience. This focus on Amazonia is also due to the strong policy demands for the development of more sustainable agricultural systems in the region, as alternatives to forms of land use that have shown significant and negative impacts on natural resources and ecosystem services, such as deforestation for extensive cattle ranching. In this scenario, agroforestry systems have been indicated as one of the more promising alternatives to achieve a more sustainable agriculture, in greater equilibrium with the environment [3].

The presence of trees in farming systems, although an ancient practice, began to gain institutional attention during the 1970s and 1980s, with the beginning of studies on "agroforestry systems". One of the principal definitions employed in this context was that proposed by Lundgren and Raintree in 1982: "Agroforestry is a collective name for landuse systems and technologies where woody perennials (trees, shrubs, palms, bamboos, etc.) are deliberately used on the same land-management units as agricultural crops and/or animals, 


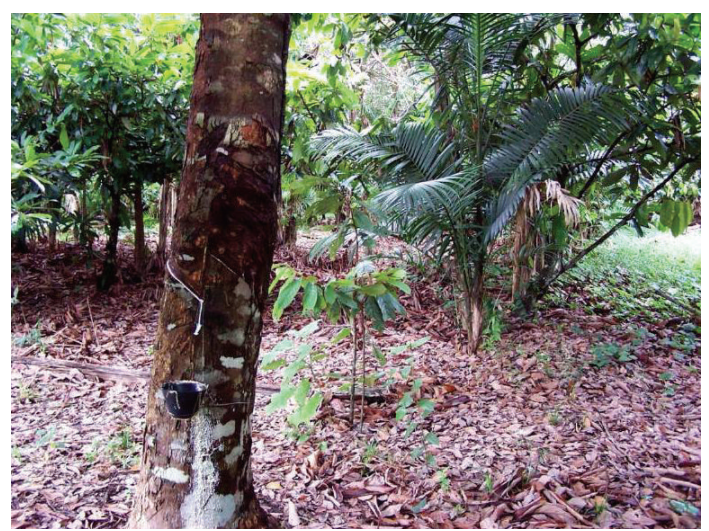

Figure 1: Agroforestry system with rubber (Hevea brasiliensis), cacao (Theobroma cacao), and açaí (Euterpe oleracea) in Tomé-açu, Pará, showing the litter layer that is typically found in such multistrata systems.

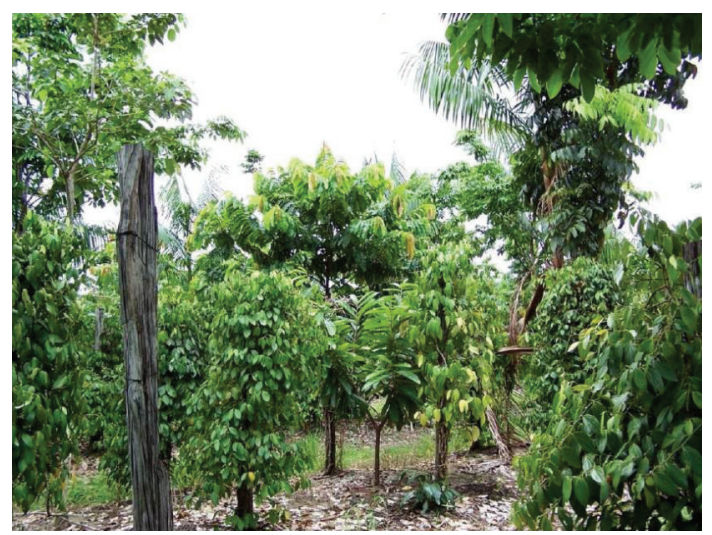

Figure 2: Agroforestry system in initial phase, with black pepper (Piper nigrum) as principal cash crop, interplanted with cupuaçu (Theobroma grandiflorum) and açaí (Euterpe oleracea) for future fruit production, as well as timber trees (mahogany-Swietenia macrophylla and ipê-Tabebuia sp.) and Brazil nut (Bertholletia excelsa) as long-term products.

in some form of spatial arrangement or temporal sequence. In agroforestry systems there are both ecological and economical interactions between the different components" [4] (Figures 1, 2, and 3).

While trees in general can provide a number of environmental benefits in both rural and urban landscapes, and play key roles in ecosystem services provided by natural areas, in this paper we will restrict our focus to the effects of trees on soil fertility, in the specific context of agricultural systems. Although the benefits that trees can provide on rural properties such as food security, household income, economic stability, and thermal comfort (shade) are most often associated with their products, such as fruit, timber, or other items, the inclusion of trees in agricultural systems can also optimize nutrient cycling and have positive effects on soil chemical and physical properties. This process is especially important in tropical soils, where a high degree of weathering has created deep, leached soils that are poor in

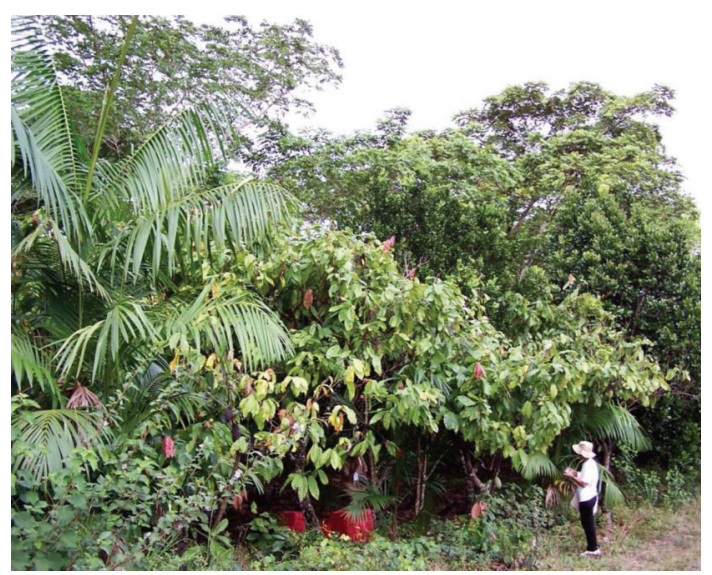

FIgure 3: Multistrata agroforestry system in Tomé-açu, Pará, with harvest of hogplum (Spondias mombin) grown as the upper canopy over cacao and açaí.

plant nutrients $[5,6]$. Although poor in nutrients, tropical soils are very rich in biodiversity, with higher diversity and biomass of microorganisms than temperate soils, with these being the principal agents mediating the supply of nutrients to the soil by means of the decomposition of organic matter, derived from the vegetation [7-9].

In the humid tropics, the removal of surface litter or organic matter generally results in the depletion of soil fertility in a few years $[10,11]$. In agricultural systems practiced by traditional peoples, this limitation is circumvented by using the land for a short period (generally 23 years), after which the cultivated areas are left to fallow with natural regeneration of secondary vegetation. The associated ecological interactions reestablish nutrient cycling and recuperate soil qualities, after which the area can once again be used for agriculture $[12,13]$. This is the basis for shifting cultivation in Amazonia, a system that has permitted native populations to manage their natural resources over centuries, with small-scale environmental impacts that do not exceed the support capacity and resilience of ecosystems. However, the present-day situation of population growth and increasing pressure on agricultural lands lead to situations where there is demand for more intensive land use. This most often implies in repeated burning, the cheapest way to prepare land for planting, which can interrupt processes of nutrient cycling and accumulation, leading to loss of soil fertility and consequently slowing the recuperation of natural vegetation during fallow cycles [14].

In light of the present-day situation of Amazonia, where there are now good reasons and policy demands to balance conservation with development, it is necessary to think in terms of agricultural systems that optimize nutrient cycling and permit permanent or semipermanent production, as well as minimize dependence on external inputs and have low environmental impact. The inclusion of diverse tree species is a key element in maintaining the production of organic matter and generating other positive benefits, as well as allowing the diversification of products. However, before we discuss topics specific to tropical soils and Amazonia, 
the following sections will review general information about the influence of trees on soil and their role in accumulation of soil carbon stocks.

\section{A General View of the Influence of Trees on Soil Fertility}

One of the pioneer studies to measure the effects of individual trees on soils was that by Zinke [15], who looked at pines growing on dunes in northern California, USA. His study found that under trees, certain soil properties exhibited a pattern of radial symmetry, with changes in $\mathrm{pH}$, nitrogen, cations, and cation exchange capacity varying according to distance from the tree trunk, with a peak in these characteristics at a certain distance.

Subsequent studies also demonstrated patterns in the variation of soil characteristics as influenced by trees, such as in tropical savannas [16, 17], deserts [18], and areas of temperate forests [19-23]. In analyzing soil characteristics under individual tree crowns in Kenyan savannas, Belsky et al. [16] found greater levels of mineralizable $\mathrm{N}$, microbial biomass, $\mathrm{P}, \mathrm{K}$, and $\mathrm{Ca}$ underneath the crowns when compared to open savanna. Burke et al. [17] explain that in dry savannas the strong limitation on water availability permits only punctuated establishment of trees and shrubs but that under crowns cycling occurs in a different form than in open grasslands, with the possibility of soil enrichment in a scale of decades. However, such soil changes can be reverted with the death of the tree or by fires. Belsky et al. [16] also point out the effect of nutrients deposited in dung by birds and large mammals that utilize trees as resting places or roosts.

Such patterns form what have been called "islands of fertility" or "resource islands" created by trees or bushes, generally in savannas or desert areas. The microenvironment of these "islands" can also influence the composition of the herb stratum $[16,19]$, soil density $[19,20]$, and earthworm activity $[20,23]$ among other factors, allowing the creation of positive feedbacks that favor plant establishment and productivity $[23,24]$. At the same time, these patterns can be important indicators of stability or risk of desertification in such areas $[17,18]$.

Studies of forests in temperate climates indicate variations in soil that can be related to individual tree species. Besides the expected correlations, such as greater levels of $\mathrm{N}$ under legumes [20] or lower $\mathrm{pH}$ under species that produce acidifying litter, such as Pinus spp. [20,23], other interesting interactions show that different species can alter soil in distinct ways, with variations in the increment of soil carbon [20], exchangeable $\mathrm{Ca}$ and $\mathrm{Mg}$ and per cent base saturation $[21,23]$.

In a study of 14 tree species in Poland, Reich et al. [23] found varied effects on soil characteristics; however, these effects were significantly related to the level of $\mathrm{Ca}$ in litter, independent of the species. Trees producing litter rich in $\mathrm{Ca}$ were associated with soils with greater $\mathrm{pH}$, exchangeable $\mathrm{Ca}$, and per cent base saturation, as well as greater rates of forest floor turnover and greater diversity and abundance of earthworms. Dijkstra [22] emphasizes that the rate of mineralization of organic $\mathrm{Ca}$ is a fundamental factor in this process, since it determines the immediate availability of this nutrient in the soil and can vary between species.

The study of vertical patterns of the distribution of nutrients in soil can indicate other phenomena that are not detected when only the horizontal distribution of nutrients is examined. In an evaluation of more than 20,000 globally distributed soil profiles, the greater part in temperate climates, Jobbágy and Jackson [25] found that cycling mediated by plants exerts a marked influence on the vertical distribution of nutrients in the soil, especially in the case of more limiting nutrients such as $\mathrm{P}$ and $\mathrm{K}$. Patterns of greater concentration of these nutrients in surface layers (0$20 \mathrm{~cm}$ ) were attributed to the fact that since these are more important to plants, they are subject to greater uptake and cycling, being absorbed from deeper layers and returned to the soil surface through litterfall and rain water throughfall. This process of uptake functions in opposition to leaching, which moves nutrients downward and acts more strongly on those nutrients that are in lessdemand by plants. If a nutrient is not limiting, its movement in the soil profile will be more influenced by leaching than by cycling and it will present higher concentrations at greater depth, as occurs with $\mathrm{Na}$, $\mathrm{Cl}$, and $\mathrm{Mg}$ [25]. In Poland, Ulery et al. [20] found this sort of pattern in soils influenced by the presence of four planted tree species, with increments of almost 3 times as much $\mathrm{K}$ in the surface layer in relation to the original soil before planting, while below $20 \mathrm{~cm}$ this increment was absent or negative. Their study also showed a high degree of leaching of $\mathrm{Na}$, which is less in demand by plants.

Associated with biological cycling and leaching, other processes that influence the vertical distribution of nutrients in soil are atmospheric deposition and weathering (Trudgill, 1988 as cited by [25]). However, atmospheric deposition is considered minor when compared to the annual uptake by plant communities and generally has little influence on the vertical distribution of nutrients $[25,26]$. The degree of weathering, however, appears to have a marked influence on the vertical distribution of nutrients, such that in more weathered soils the pattern of concentration in the surface layer is accentuated [25]. This emphasizes the importance of biological cycling in supplying nutrients in weathered soils, as is found in the greater part of the tropics and will be discussed in a subsequent section.

\section{Trees and Soil Carbon}

Trees add organic matter to the soil system in various manners, whether in the form of roots or litterfall or as root exudates in the rhizosphere [27]. These additions are the chief substrate for a vast range of organisms involved in soil biological activity and interactions, with important effects on soil nutrients and fertility. In participating in these complex processes, trees contribute to carbon accumulation in soils, a topic that is increasingly present in discussions on the mitigation of greenhouse gases associated with global warming and climate change. Although carbon (C) constitutes almost $50 \%$ of the dry weight of branches and 
$30 \%$ of foliage, the greater part of $\mathrm{C}$ sequestration (around $2 / 3$ ) occurs belowground, involving living biomass such as roots and other belowground plant parts, soil organisms, and C stored in various soil horizons [28].

In a study that gathered information from sites around the world, Nair et al. [29] found values for soil organic C stocks ranging from 6.9 to $302 \mathrm{Mgha}^{-1}$. Despite the great amplitude of these values, attributed to the variation between systems, ecological regions, and soil types, the study revealed a general trend of increasing soil $\mathrm{C}$ sequestration in agroforestry when compared to other land-use practices, with the exception of forests.

Although the ability of soils to accumulate $\mathrm{C}$ is generally related to characteristics that are little influenced by management, such as texture (clay soils typically accumulate more $\mathrm{C}$ than sandy soils), some management practices can influence soil $\mathrm{C}$ sequestration, particularly the insertion of trees in agricultural systems. Soils in various sites studied by Takimoto et al. [30] in the African Sahel were not markedly different among each other in terms of their characteristics such as $\mathrm{pH}$, bulk density, and particle size, such that variations in their $\mathrm{C}$ contents seemed to be related to the influence of trees. In 8-year-old alley-cropping systems with five different species, for example, the authors found that greater $\mathrm{C}$ content is nearer to the trees. However, the greater part of this $\mathrm{C}$ was found in the form of particles of size between 250-2000 $\mu \mathrm{m}$, fractions that are considered to be large and less stable. In systems where trees where present for more than 30 years (parklands), there was a predominance of soil $\mathrm{C}$ in smaller fractions $(<53 \mu \mathrm{m})$, which are more stable and thus represent a more "protected" form of C.

In homegardens in India, Saha et al. [31] found levels of soil organic C to be $30 \%$ and $114 \%$ greater than in coconut plantations and rice paddies, respectively, when homegardens where small (less than $0.4 \mathrm{ha}$ ) and levels $18 \%$ and $94 \%$ greater in larger homegardens (larger than 0.4 hectares). Although the authors do not elaborate on the reasons for decrease in soil $\mathrm{C}$ in the larger homegardens, this may be related to a drop off in the deposition of organic residues, which generally occurs in proximity to dwellings. In the Northeast of Spain, Howlett et al. [32] studied the levels of soil C in silvopastoral systems composed of different species, and found that systems with birch (Betula pendula) presented greater levels of soil $\mathrm{C}$ than systems with pine (Pinus radiata). This difference was attributed to the fact that $P$. radiata create an understory environment that is less conductive to plant growth by the formation of a slowly decomposing duff layer, which inhibits germination and growth of other species and, over time, reduces $\mathrm{C}$ inputs to the soil. Both silvopastoral systems presented levels of $\mathrm{C}$ similar to pastures without trees, and in the case of the more stable $C$ fractions $(<53 \mu \mathrm{m})$ in the upper layers $(0-50 \mathrm{~cm})$, the pasture without trees presented greater levels than the silvopastoral systems. However, the authors observed that these levels may not accurately represent long-term $\mathrm{C}$ sequestration potential, since pasture tillage led to more free (unoccluded) silt+clay-sized fraction recovery, which translated into more storage in the pasture as compared with the pine and birch stands. In other situations tillage is reported to cause significant loss of surface soil organic C and disruption of the process of macroaggregate formation, increasing bioavailable sources of $\mathrm{C}$ from smaller aggregates [28, 30-32]. Tonucci et al. [33] consider that on the short term, C levels in pasture soils can be greater than under systems with trees due to the faster turnover of the grass root system, as well as the greater bulk density of soils in pasture systems, that can lead to higher $\mathrm{C}$ values than found in less dense soils.

The lag inachieving positive results in terms of soil $\mathrm{C}$ accumulation under trees are similar to what has been observed in the transition to continuous no-till agriculture. According to Derpsch et al. [34], clear increases in soil organic matter only appear 5-10 years after the adoption of this form of cropping system. Climate conditions also affect $\mathrm{C}$ accumulation in soils, since temperature and humidity greatly affect the activity of microbial communities and the breakdown of organic matter [28]. Takimoto et al. [30], for example, attributed, at least partly, To the low levels of $\mathrm{C}$ found in their study of soils in the African Sahel to the high temperatures in that region.

\section{Trees and Soil Biodiversity}

In Amazonia, the diversity and density of macroinvertebrates in the soils of natural forests are considered high, and the conversion of these ecosystems to other forms of land use can cause severe changes in their populations $[35,36]$. Barros et al. [37] cite soil macroinvertebrates as sensitive indicators of natural systems, land use, and management, with agroforestry systems presenting a greater abundance and diversity when compared to other forms of agricultural land use. Tapia-Coral et al. [38] found greater densities and biomass of Diplopoda and Isopoda in the litter layer of agroforestry systems than in adjacent secondary forests. Secondary forests, however, presented greater values for Isoptera, principally during the rainy season. This is an indication that such systems can support sufficiently abundant and diverse communites of these organisms that play an important role in ecological processes such as breakdown and cycling of organic matter. However, agroforestry systems encompass a range of practices, such that there is considerable variation in the quality of organic matter produced and the effects of vegetation on soil humidity and temperature regime, with significant effects on the soil macrofauna community [37].

In a study to evaluate the occurrence and diversity of arbuscular mycorrhizal fungi in soil under different land uses in Amazonia (high forest, old secondary forest, young secondary forests, agroforestry systems, crops, and pasture), Leal et al. [39] found great variation in species richness among samples, independent of the land use system. On the other hand, in these same systems Jesus et al. [40] observed that the principal differences in the composition and structure of the bacterial community were related to alterations in soil attributes, which in turn are correlated to land use. Community structure changed significantly along gradients of cation saturation and $\mathrm{pH}$. The similarity observed between 
the communities of primary and secondary forest indicates the recuperation of the bacterial community during the process of succession that occurs after the abandonment of areas used for agriculture, with the return of arboreal vegetation.

\section{Trees on Tropical Soils}

In contrast to temperate ecosystems, where soils generally are more fertile and a greater part of the nutrients is supplied by the weathering of parent material, conditions of high temperatures and rainfall in the tropics accelerate soil processes, including loss of nutrients, so that the greater stock of nutrients is found held in the biomass and made available through decomposition [5-7, 9]. Although there are exceptions to this rule, such as soils of more recent volcanic origin in Asia, or the floodplains of the Amazon River that annually receive sediments from the Andes, the majority of soils in the Amazon Basin are typical examples of low-fertility tropical soils, having been formed on ancient sediments. The high temperature and humidity of tropical climates are conducive to the decomposition of organic matter, so that there is not only the release of nutrients but also the formation of negatively charged particles, which help to retain cations such as $\mathrm{K}, \mathrm{Ca}$, and $\mathrm{Mg}$ and maintain them in constant interface with the soil solution, where they can be absorbed by plants. In tropical systems, therefore, a soil cover of organic matter is essential to maintain adequate conditions for the soil micro, meso, and macrofauna that carry out this cycling [41]. As such, many of the studies on the effects of trees on tropical soil concentrate on the importance of organic matter made available in great part through litterfall.

Litter production can be a very important contribution in systems where perennial crops such as cacao and coffee are grown under the shade of trees. Souza et al. [42] observed that litter production in a coffee plantation shaded with diverse tree species was similar to that of native forests in the same region. Araujo and Collier [43], working in an agroforestry system with four fruit trees in a transition region between savanna and Amazonian forest in Brazil, indicated the importance of litterfall in the dry season, when compared to conventional cropping systems. Jaramillo-Botero et al. [44], in analyzing the effects of native trees planted as shade for coffee in southeastern Brazil, found that the quantity of accumulated litter and level of $\mathrm{K}$ in the soil was positively influenced by the number of trees present in a distance of 0 to 3 meters from the coffee bushes. Since $K$ is a very mobile element, $\mathrm{K}$ enrichment may be partly due to throughfall and stemflow, as observed by Pinho et al. [45] in coffee agroforestry systems in the same region. Also in coffee systems, Jesus et al. [46] found higher $\mathrm{pH}$ and base saturation in areas intercropped with rubber (Hevea brasiliensis) than in monocultures. These studies suggest that roots of trees occupy deeper soil layers that may not be accessible to other crops, or that they are more efficient in extracting nutrients, due to their greater size and biomass or to other factors such as mycorrhizal associations. As such, when compared to other agricultural systems in tropical conditions, agroforestry can accumulate greater amounts of carbon and can help maintain soil fertility through a more efficient cycling of nutrients and a reduction of losses through leaching and erosion.

In a number of situations, intercropping with legume species that fix atmospheric $\mathrm{N}$ means that this element will be provided through decomposition to other plants, a practice commonly known as "green manuring" [47, 48]. Mochiutti and Queiroz [49], working in the state of Amapá, eastern Amazonia, found that $\mathrm{N}$ levels were two times higher in the litter under improved fallows planted with the native legume taxi-branco (Sclerolobium paniculatum), when compared to fallows with natural regeneration. In a floodplain ecosystem in central Amazonia, Kreibich et al. [50] found that the flux of mineral $\mathrm{N}$ in the soil at $0-20 \mathrm{~cm}$ was 3 -fold greater under native legume species than under nonlegumes, indicating the importance of legumes in that ecosystem.

A continent-wide study in Africa found that green manuring increases maize production, with important benefits for food security $[51,52]$. The great variety of legume species with potential for use as green manures offers a number of possibilities for intercropping. Quick-growing herbaceous species include Cajanus cajan, Crotalaria juncea, Stizolobium aterrimum, and Calopogonium mucunoides, which decompose rapidly and improve soil within 2-3 months [5355]. In contrast, tree legumes with slower growth, such as Gliricidia sepium and Leucaena leucocephala, are important for supplying organic matter with different characteristics, such as greater $\mathrm{C} / \mathrm{N}$ ratios, polyphenol, or lignin contents. While organic matter with a low $\mathrm{C} / \mathrm{N}$ ratio will decompose more quickly and rapidly releasing nutrients for use by crop plants, in certain situations a slower decomposition rate may be desirable, in order to maintain soil cover and control growth of weeds $[56,57]$.

However, the diversification of species is important to also diversify the characteristics of the biomass that are generated and incorporated in the soil, such that there is better mix in terms of nutrient contents. This may require planting or managing other species, besides legumes. In the study previously cited by Mochiutti and Queiroz [49] it was found that litter produced in an area with natural secondary forest regeneration had a higher content of $\mathrm{Ca}$ than litter from the area planted with the legume taxibranco. A study by Gonçalvez et al. [58], in the Atlantic Rainforest of Brazil, found marked differences in levels of macro- and micronutrients in litter produced by native tree species, reinforcing the need to consider a mix of species in agroforestry systems.

\section{Trees in Amazonian Agriculture}

Over millennia, traditional populations have diversified their agricultural systems with trees, and intentionally or not, have benefitted from their products and other services that result from this management. In Amazonia, many indigenousl societies and their multiracial descendants, 


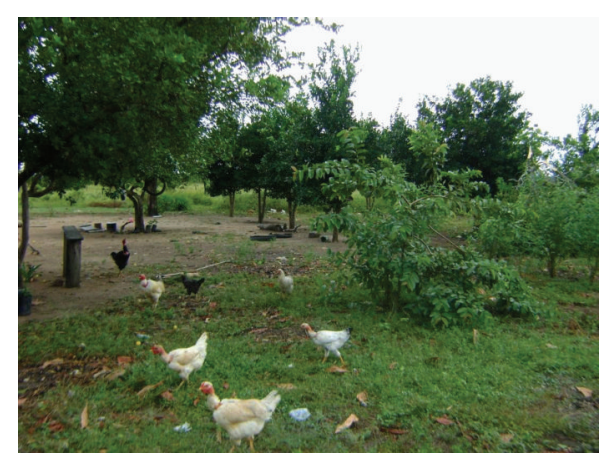

(a)

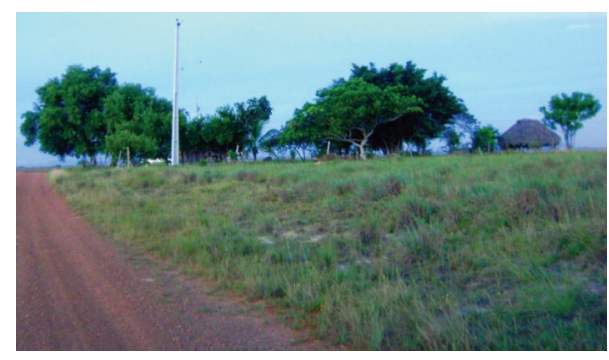

(c)

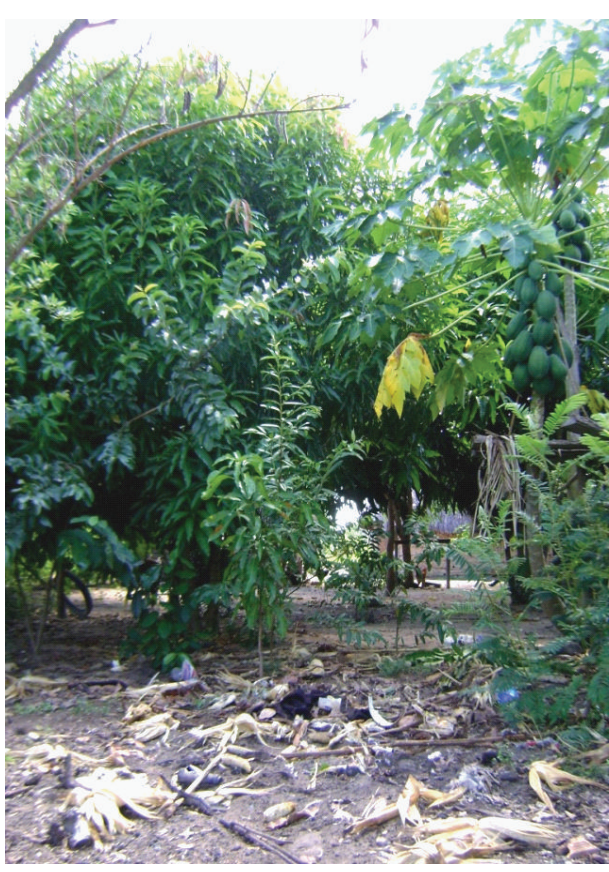

(b)

FIGURE 4: (a) Delimitation between the swept and weeded bare earth "yard" that surrounds the dwelling (left) and the outside area (periphery) where the residues are directed to (right). (b) Accumulation of organic domestic residues in the periphery of a homegarden, where frequent small burns of these residues may occur, together with other organic materials derived from sweeping and weeding the "yard"; (c) outside view of an indigenous homegarden in the "Lavrado" (savanna) of Roraima, Brazil (Araçá Indigenous Land, Brazil).

the caboclos or ribereños, practice forms of agriculture involving trees, whether in homegardens around their dwellings or more extensive systems involving intercropping in swidden fields [59-61]. These practices consist of a set of techniques developed by traditional populations over the years or centuries, based on observation and experimentation.

According to Clement [62], when Europeans first arrived in the Americas, Amazonian communities had already domesticated more than 130 species, of which around 80 are fruit bearing, such as avocado (Persea americana), abiu (Pouteria caimito), biribá (Rollinia mucosa), cashew (Anacardium occidentale), genipap (Genipa americana), papaya (Carica papaya), passion fruit (Passiflora edulis), and murici (Byrsonima crassifolia), among others. It is believed that the domestication of plants and other management practices of tree species originally occurred in areas surrounding dwellings, where discarded seeds of wild species may have germinated, to be cultivated by observant protofarmers [63, 64]. In the locations around dwelling the deposition of residues resulting from domestic activities is commonplace (husks, bones, ashes, etc.) and has led to the creation of some of the most productive soils in Amazonia, the "black earths" or "terra preta de indio" [56, 65-67].

Many of the practices that created such soils are still in use today, as can be observed in the modern-day homegardens of indigenous and caboclo farmers, which have a diversity of tree species, frequent additions of organic matter as well as occasional low-intensity burning of residues
[64, 68-73] (Figure 4). In indigenous communities of the Lavrado (savanas) region of Roraima, northern Brazil, homegardens have a great variety of plants, mostly fruit bearing and are important to food security [74]. In a study of soil nutrients under a chronosequence of these homegardens in Araçá Indigenous Land, Roraima, Pinho et al. [75] found a progressive increase in levels of $\mathrm{P}, \mathrm{K}, \mathrm{Ca}, \mathrm{Mg}$, organic matter, and $\mathrm{pH}$, as well as a decrease in $\mathrm{Al}$ (Table 1). In these otherwise infertile savanna soils [76], cultivation of fruit trees around dwellings is made possible by this gradual increment in nutrients, a result of nutrient imports from surrounding ecosystems, deposited in the form of residues and possibly the internal cycling by trees that also contribute to the system by means of their litter.

While dwellings and associated homegardens represent relatively stable features on the landscape, slash-and-burn or swidden agriculture fields shift around a broader area, because for every field under cultivation, a greater area must be kept recovering under a fallow of secondary vegetation. Under low population density, this traditional system is adequate for crop production, with long fallows between cropping cycles guaranteeing the recovery of soil physical and chemical qualities. However, with population growth and pressure on land, more areas of forest are being converted to agriculture, with a concurrent reduction in fallow cycles, such that the sustainability of this system is threatened by reduced soil fertility [14]. In the savanna region of Roraima, intensive agricultural use of the scattered forest patches or 
TABLE 1: Levels of nutrients, organic matter, and acidity, by depth, in homegardens and savanna soils in Araçá Indigenous Land, Roraima, and Brazil. Homegarden values followed by ${ }^{*}$ or ${ }^{* *}$ are statistically different from savannas, with $P \leq 0,05$ and $P \leq 0,001$, respectively, by Mann-Whitney test ( $U$-test).

\begin{tabular}{|c|c|c|c|c|}
\hline & $\begin{array}{l}\text { Savanna } \\
(n=15)\end{array}$ & $\begin{array}{c}\text { New homegardens } \\
(n=5)(0-10 \text { years-old })\end{array}$ & $\begin{array}{l}\text { Estabilished homegardens } \\
(n=5)(15-35 \text { years-old })\end{array}$ & $\begin{array}{c}\text { Old homegardens } \\
(n=5)(40+\text { years old })\end{array}$ \\
\hline \multicolumn{5}{|l|}{$\mathrm{P}\left(\mathrm{mg} \mathrm{Kg}^{-1}\right)$} \\
\hline $0-10 \mathrm{~cm}$ & 2,1 & $14,3^{* *}$ & $26,5^{* *}$ & $43,7^{* *}$ \\
\hline $10-20 \mathrm{~cm}$ & 1,1 & $8,5^{*}$ & $12,2^{* *}$ & $37,9^{* *}$ \\
\hline $20-30 \mathrm{~cm}$ & 0,6 & $7,5^{*}$ & $7,5^{* *}$ & $31,2^{* *}$ \\
\hline \multicolumn{5}{|c|}{$\mathrm{K}\left(\mathrm{cmolc} \mathrm{Kg}^{-1}\right)$} \\
\hline $0-10 \mathrm{~cm}$ & 0,07 & 0,08 & $0,11^{*}$ & $0,18^{* *}$ \\
\hline $10-20 \mathrm{~cm}$ & 0,06 & 0,08 & $0,10^{*}$ & $0,15^{* *}$ \\
\hline $20-30 \mathrm{~cm}$ & 0,06 & 0,07 & $0,10^{*}$ & $0,13^{* *}$ \\
\hline \multicolumn{5}{|c|}{$\mathrm{Ca}\left(\mathrm{cmolc} \mathrm{Kg}^{-1}\right)$} \\
\hline $0-10 \mathrm{~cm}$ & 0,32 & $0,66^{*}$ & $1,48^{*}$ & $1,93^{* *}$ \\
\hline $10-20 \mathrm{~cm}$ & 0,22 & 0,24 & $1,02^{*}$ & $1,41^{* *}$ \\
\hline $20-30 \mathrm{~cm}$ & 0,17 & 0,18 & $0,63^{*}$ & $1,03^{* *}$ \\
\hline \multicolumn{5}{|c|}{$\mathrm{Mg}\left(\mathrm{cmolc} \mathrm{Kg}^{-1}\right)$} \\
\hline $0-10 \mathrm{~cm}$ & 0,16 & 0,18 & 0,30 & $0,48^{* *}$ \\
\hline $10-20 \mathrm{~cm}$ & 0,09 & 0,10 & $0,24^{* *}$ & $0,33^{* *}$ \\
\hline $20-30 \mathrm{~cm}$ & 0,06 & 0,07 & $0,18^{*}$ & $0,28^{* *}$ \\
\hline \multicolumn{5}{|l|}{$\mathrm{Fe}\left(\mathrm{mg} \mathrm{Kg}^{-1}\right)$} \\
\hline $0-10 \mathrm{~cm}$ & 25,2 & 21,4 & 39,8 & $135,6^{*}$ \\
\hline $10-20 \mathrm{~cm}$ & 22,7 & 17,8 & 37,4 & $104,4^{*}$ \\
\hline $20-30 \mathrm{~cm}$ & 20,3 & 12,6 & 26,5 & $81,0^{*}$ \\
\hline \multicolumn{5}{|l|}{$\mathrm{Zn}\left(\mathrm{mg} \mathrm{Kg}^{-1}\right)$} \\
\hline $0-10 \mathrm{~cm}$ & 1,9 & 3,1 & $12,9^{* *}$ & $13,9^{* *}$ \\
\hline $10-20 \mathrm{~cm}$ & 2,1 & 1,5 & $8,11^{* *}$ & $11,6^{* *}$ \\
\hline $20-30 \mathrm{~cm}$ & 2,6 & 1,4 & $8,63^{* *}$ & $11,4^{*}$ \\
\hline \multicolumn{5}{|l|}{$\mathrm{Mn}\left(\mathrm{mg} \mathrm{Kg}^{-1}\right)$} \\
\hline $0-10 \mathrm{~cm}$ & 22,4 & 32,4 & 29,91 & 40,6 \\
\hline $10-20 \mathrm{~cm}$ & 16,7 & 23,9 & 18,02 & 24,7 \\
\hline $20-30 \mathrm{~cm}$ & 15,3 & 23,4 & 14,93 & 18,5 \\
\hline \multicolumn{5}{|l|}{$\mathrm{Cu}\left(\mathrm{mg} \mathrm{Kg}^{-1}\right)$} \\
\hline $0-10 \mathrm{~cm}$ & 0,86 & 0,74 & 1,70 & 1,17 \\
\hline $10-20 \mathrm{~cm}$ & 0,87 & 0,67 & 1,37 & 1,17 \\
\hline $20-30 \mathrm{~cm}$ & 0,84 & 0,62 & 1,28 & 1,13 \\
\hline \multicolumn{5}{|c|}{ Organic matter $\left(\mathrm{g} \mathrm{Kg}^{-1}\right)$} \\
\hline $0-10 \mathrm{~cm}$ & 12,9 & 12,2 & 20,6 & $27,6^{* *}$ \\
\hline $10-20 \mathrm{~cm}$ & 10,0 & 7,9 & 14,6 & $19,5^{*}$ \\
\hline $20-30 \mathrm{~cm}$ & 8,3 & 6,9 & 10,4 & $14,3^{*}$ \\
\hline \multicolumn{5}{|l|}{$\mathrm{Al}\left(\mathrm{mg} \mathrm{Kg}^{-1}\right)$} \\
\hline $0-10 \mathrm{~cm}$ & 0,13 & 0,07 & 0,08 & $0,05^{*}$ \\
\hline $10-20 \mathrm{~cm}$ & 0,17 & 0,12 & 0,09 & 0,08 \\
\hline $20-30 \mathrm{~cm}$ & 0,19 & 0,11 & 0,11 & 0,10 \\
\hline \multicolumn{5}{|l|}{$\mathrm{pH}\left(\mathrm{H}_{2} \mathrm{O}\right)$} \\
\hline $0-10 \mathrm{~cm}$ & 5,34 & 5,39 & 5,48 & 5,45 \\
\hline $10-20 \mathrm{~cm}$ & 5,16 & 5,28 & 5,39 & 5,49 \\
\hline $20-30 \mathrm{~cm}$ & 5,13 & 5,29 & 5,30 & 5,32 \\
\hline
\end{tabular}


islands, with shorter fallow cycles, has led to a reduction in soil fertility and a greater proportion of the area under secondary forest. A study by Freitas [77] showed that in this situation fallows, can contribute to an increase in soil $\mathrm{P}$ but not to an increase in $\mathrm{K}$, suggesting that these two nutrients are limiting factors for agricultural production in the forest islands. On the other hand, in a cambisol in the Upper Solimões region, Soares [78] observed that five years of fallow were the minimum time necessary to achieve levels of exchangeable $\mathrm{Ca}$ and $\mathrm{Mg}$ equivalent to that found in twenty year-old fallows.

Modern agricultural technologies offer the possibility of continuous crop production in the same area, without the need for fallows, through the use of machinery and chemical inputs. However, this model of agricultural production can lead to soil erosion as well to the reduction in biological processes that are important in tropical soils, along with a dependence on external inputs [9]. Based on the soil improvement that naturally occurs under secondary forests, lessons can be obtained as to the possibility of including trees as components of a more sustainable agriculture for Amazonia [79]. Choices as to which tree species to include can consider those that offer useful products or that speed-up processes of soil improvement, such as legumes that provide green manures.

A recently released study classifying land use in areas deforested up to 2007 in the Brazilian Amazon indicates that $62.2 \%$ of the area deforested has been occupied by pastures. In productive terms, however, $25 \%$ of the area under pasture can be considered as degraded or "weedy" [80]. Such areas left behind the advancing agricultural frontier are now the prime concern for initiatives of landscape recovery that seek to restore ecosystem services, such as riparian buffer strips to protect hydrological resources and provide connectivity for other landscape functions such as biodiversity. Current Brazilian environmental legislation requires that rural properties in Amazonia maintain $80 \%$ of their area with forest cover, a figure that is reduced to $50 \%$ in regions that have established a zoning system. As a result, many properties must recuperate areas that were deforested if they wish to access government programs such as agricultural credit. While ecological restoration can be quite expensive on its own, recuperation of areas of degraded pasture with agroforestry systems for production of food, commodities, and timber products may be a viable alternative. Choice of the proper tree species is critical to the success of any such initiatives, not just from an economic point of view, but also from the biological point of view in terms of rejuvenating soil properties.

Research with native legumes in Amazonia has shown that more than $60 \%$ are nodulating species $[81,82]$ and thus have a great potential for use in agroforestry. Other tree species may be chosen based on either ecological or production functions. However, planning of successful agroforestry systems must alsoconsider cash flows and choose appropriate species accordingly.

Although the number of practical examples is limited, another potential role of trees in Amazonian production systems is as components of silvopastoral systems. Andrade et al. [83] indicate that at least one legume species, Stryphnodendron guianensis, has positive effects on soil fertility and forage production. However, this is due in part to this tree's crown architecture, which does not create an excess of shade.

\section{Conclusions}

Trees in agroecosystems can be present in an infinite number of arrangements and species combinations that depend mostly on farmers' objectives as well as the environmental characteristics of the region. In general, it is safe to say that a greater diversity of species is more favorable, as it results in a more complete occupation of space above and below the soil, and the variation in the characteristics of the litter produced can maintain a greater level of soil biodiversity, with positive effects on fertility [10,79].

The intentional use of trees in farming systems occurs in many parts of the globe; however, many of their benefits, that go much beyond soil improvement, are still difficult to visualize or quantify in economic terms or only appear in the long term $[47,84]$, such that many farmers are hesitant to invest in trees. A better understanding of the positive effects of trees on soils, and an economic analysis of what this represents in terms of nutrients and other benefits, is an important step towards increasing the use of trees on farms.

Soil improvement under trees and agroforestry systems is in great part related to increases in organic matter, whether in the form of surface litter or soil carbon. Therefore, besides their role in above-ground carbon sequestration, agroforestry systems also have a great potential to increase carbon stocks in the soil and certainly merit consideration in mechanisms that propose payments for mitigation of greenhouse gas emissions to reduce climate change.

\section{References}

[1] R. J. Zomer, A. Trabucco, R. Coe, and F. Place, Trees on Farm: Analysis of Global Extent and Geographical Patterns of Agroforestry, ICRAF Working Paper no. 89, World Agroforestry Centre, Nairobi, Kenya, 2009.

[2] World Agroforestry Centre, 2008, http://www.worldagroforestry.org/downloads/publications/PDFS/B15732.pdf.

[3] R. Porro, Ed., Alternativa agroflorestal na Amazônia em transformação, Embrapa Informação Tecnológica, Brasília, Brazil, 2009.

[4] P. K. R. Nair, Agroforestry Systems in the Tropics, Kluwer, Norwell, Mass, USA, 1989.

[5] R. E. Ricklefs, A Economia da Natureza, Guanabara Koogan, Rio de Janeiro, Brazil, 3rd edition, 1996.

[6] A. Primavesi, "A fertilidade do solo," Agroecologia Hoje, vol. 8, article 5, 2001.

[7] F. J. Luizao, "Litter production and mineral element input to the forest floor in a Central Amazonian forest," GeoJournal, vol. 19, no. 4, pp. 407-417, 1989.

[8] P. M. Fearnside and R. I. Barbosa, "Soil carbon changes from conversion of forest to pasture in Brazilian Amazonia," Forest Ecology and Management, vol. 108, no. 1-2, pp. 147-166, 1998.

[9] A. Primavesi, Manejo ecológico do solo: a agricultura em regiões tropicais, Nobel, São Paulo, Brazil, 2002. 
[10] F. J. Luizão and R. C. C. Luizão, "Matéria orgânica do solo em Roraima," in Homem, Ambiente e Ecologia no Estado de Rorai$m a$, R. I. Barbosa, E. J. G. Ferreira, and E. G. Castellón, Eds., pp. 363-376, INPA, Manaus, Brazil, 1997.

[11] S. J. F. Ferreira, F. J. Luizão, S. Á. F. Miranda, M. D. S. R. Da Silva, and A. R. T. Vital, "Nutrients in soil solution in an upland forest submitted to selective logging in central Amazonia," Acta Amazonica, vol. 36, no. 1, pp. 59-68, 2006.

[12] P. J. Kleinman, D. Pimentel, and R. B. Bryant, "The ecological sustainability of slash-and-burn agriculture," Agriculture, Ecosystems and Environment, vol. 52, no. 2-3, pp. 235-249, 1995.

[13] P. Santilli, "Ocupação territorial Macuxi: aspectos históricos e políticos," in Homem, Ambiente e Ecologia no Estado de Roraima, R. I. Barbosa, E. J. G. Ferreira, and E. G. Castellón, Eds., pp. 49-64, INPA, Manaus, Brazil, 1997.

[14] M. Mazoyer and L. Roudart, História das agriculturas no mundo: do neolítico à crise contemporânea, UNESP, São Paulo and NEAD, Brasília, Brazil, 2010.

[15] P. J. Zinke, "The pattern of influence of individual forest trees on soil properties," Ecology, vol. 43, pp. 130-133, 1962.

[16] A. J. Belsky, R. G. Amundson, J. M. Duxbury, S. J. Riha, A. R. Ali, and S. M. Mwonga, "The effects of trees on their physical, chemical, and biological environments in a semi-arid savanna in Kenya," Journal of Applied Ecology, vol. 26, no. 3, pp. 10051024, 1989.

[17] I. C. Burke, W. K. Lauenroth, M. A. Vinton et al., "Plant-soil interactions in temperate grasslands," Biogeochemistry, vol. 42, no. 1-2, pp. 121-143, 1998.

[18] W. H. Schlesinger, J. A. Raikks, A. E. Hartley, and A. F. Cross, "On the spatial pattern of soil nutrients in desert ecosystems," Ecology, vol. 77, no. 2, pp. 364-374, 1996.

[19] W. E. Frost and S. B. Edinger, "Effects of tree canopies on soil characteristics of annual rangeland," Journal of Range Management, vol. 44, no. 3, pp. 286-288, 1991.

[20] A. L. Ulery, R. C. Graham, O. A. Chadwick, and H. B. Wood, "Decade-scale changes of soil carbon, nitrogen and exchangeable cations under chaparral and pine," Geoderma, vol. 65, no. 1-2, pp. 121-134, 1995.

[21] A. C. Finzi, C. D. Canham, and N. Van Breemen, "Canopy tree-soil interactions within temperate forests: species effects on $\mathrm{pH}$ and cations," Ecological Applications, vol. 8, no. 2, pp. 447-454, 1998.

[22] F. A. Dijkstra, "Calcium mineralization in the forest floor and surface soil beneath different tree species in the northeastern US," Forest Ecology and Management, vol. 175, no. 1-3, pp. 185-194, 2003.

[23] P. B. Reich, J. Oleksyn, J. Modrzynski et al., "Linking litter calcium, earthworms and soil properties: a common garden test with 14 tree species," Ecology Letters, vol. 8, no. 8, pp. 811$818,2005$.

[24] R. J. Scholes and S. R. Archer, "Tree-grass interactions in Savannas," Annual Review of Ecology and Systematics, vol. 28, pp. 517-544, 1997.

[25] E. G. Jobbágy and R. B. Jackson, "The distribution of soil nutrients with depth: global patterns and the imprint of plants," Biogeochemistry, vol. 53, no. 1, pp. 51-77, 2001.

[26] M. Arianoutsou, "Atmospheric deposition of nutrients in a coastal maquis ecosystem of northeastern Greece," International Journal of Biometeorology, vol. 33, no. 2, pp. 124-130, 1989.

[27] C. Bertin, X. Yang, and L. A. Weston, "The role of root exudates and allelochemicals in the rhizosphere," Plant and Soil, vol. 256, no. 1, pp. 67-83, 2003.
[28] P. K. R. Nair, V. D. Nair, B. Mohan Kumar, and J. M. Showalter, "Carbon sequestration in agroforestry systems," Advances in Agronomy, vol. 108, pp. 237-307, 2010.

[29] P. K. R. Nair, B. M. Kumar, and V. D. Nair, "Agroforestry as a strategy for carbon sequestration," Journal of Plant Nutrition and Soil Science, vol. 172, no. 1, pp. 10-23, 2009.

[30] A. Takimoto, P. K. R. Nair, and V. D. Nair, "Carbon stock and sequestration potential of traditional and improved agroforestry systems in the West African Sahel," Agriculture, Ecosystems and Environment, vol. 125, no. 1-4, pp. 159-166, 2008.

[31] S. K. Saha, P. K. R. Nair, V. D. Nair, and B. M. Kumar, "Carbon storage in relation to soil size-fractions under tropical treebased land-use systems," Plant and Soil, vol. 328, no. 1, pp. 433-446, 2010.

[32] D. S. Howlett, M. R. Mosquera-Losada, P. K. R. Nair, V. D. Nair, and A. Rigueiro-Rodrigues, "Soil carbon storage in silvopastoral systems and a treeless pasture in northwestern Spain," Journal of Environmental Quality, vol. 40, no. 3, pp. 825-832, 2011.

[33] R. G. Tonucci, P. K. R. Nair, V. D. Nair, R. Garcia, and F. S. Bernardino, "Soil carbon storage in silvopasture and related land-use systems in the Brazilian Cerrado," Journal of Environmental Quality, vol. 40, no. 3, pp. 833-841, 2011.

[34] R. Derpsch, "No-tillage and conservation agriculture: a progress report," in No-Till Farming Systems, T. Goddard, M. Zoebisch, Y. Gan, W. Ellis, A. Watson, and S. Sombatpanit, Eds., pp. 7-39, World Association of Soil and Water Conservation. Special Publication No. 3, 2008.

[35] P. Lavelle and B. Pashanasi, "Soil macrofauna and land management in Peruvian Amazonia (Yurimaguas, Loreto)," Pedobiologia, vol. 33, no. 5, pp. 283-292, 1989.

[36] P. Lavelle, A. Chauvel, and C. Fragoso, "Faunal activity in acid soils," in Plant Soil Interactions at Low pH, R. A. Date, Ed., pp. 201-211, Springer, Berlin, Germany, 1995.

[37] E. Barros, J. Mathieu, S. Tapia-Coral, A. R. L. Nascimento, and P. Lavelle, "Comunidades da macrofauna do solo da Amazônia Brasileira," in Biodiversidade do Solo em Ecossistemas Brasileiros, F. M. S. Moreira, J. O. Siqueira, and L. Brussaard, Eds., pp. 171-191, Editora UFLA, Minas Gerais, Brazil, 2008.

[38] S. C. Tapia-Coral, F. J. Luizão, and E. V. Wandelli, "Macrofauna da liteira em sistemas agroflorestais sobre pastagens abandonadas na Amazônia Central," Acta Amazônica, vol. 29, no. 3, pp. 447-495, 1999.

[39] P. L. Leal, S. L. Stürmer, and J. O. Siqueira, "Occurrence and diversity of arbuscular mycorrhizal fungi in trap cultures from soils under different land use systems in the amazon, Brazil," Brazilian Journal of Microbiology, vol. 40, no. 1, pp. 111-121, 2009.

[40] E. D. C. Jesus, T. L. Marsh, J. M. Tiedje, and F. M. D. S. Moreira, "Changes in land use alter the structure of bacterial communities in Western Amazon soils," ISME Journal, vol. 3, no. 9, pp. 1004-1011, 2009.

[41] P. Lavelle, E. Barros, E. Blanchart et al., "SOM management in the tropics: why feeding the soil macrofauna?" Nutrient Cycling in Agroecosystems, vol. 61, no. 1-2, pp. 53-61, 2001.

[42] V. V. Souza, R. C. Pinho, and I. Jucksch, "Produção e composição de serrapilheira em um sistema agroflorestal com café (Coffea arabica) em Viçosa-MG," in Anais do V Congresso Brasileiro de Sistemas Agroflorestais, Curitiba, Brazil, 2004.

[43] G. P. Araujo and L. S. Collier, "Parâmetros de fertilidade dos solos em sistemas agroflorestais em Esperantina-TO," in Anais 
do VI Congresso Brasileiro de Sistemas Agroflorestais, Campos, Brazil, 2006.

[44] C. Jaramillo-Botero, R. H. S. Santos, Junior P. Marco, T. M. Pontes, P. Fardin, and F. Sarmento, "Efeito da distribuição espacial das árvores sobre a produção de cafeeiros em sistema agroflorestal na zona da mata de Minas Gerais, Brasil," in Anais do VI Congresso Brasileiro de Sistemas Agroflorestais, Campos, Brazil, 2006.

[45] R. C. Pinho, V. V. Souza, and I. Jucksch, "Contribuição de espécies arbóreas na ciclagem de nutrientes via precipitação em um sistema agroflorestal com café (Coffea arabica) no município de Viçosa, MG," in Anais do IV Congresso Brasileiro de Sistemas Agroflorestais, Ilhéus, Brazil, 2002.

[46] J. Jesus, M. S. Bernardes, C. A. Righi, A. M. P. Lunz, J. L. Favarin, and F. T. Camargo, "Avaliação da fertilidade do solo e teor foliar de K do cafeeiro (Coffea arabica L.) em sistema agroflorestal em aléia de seringueira (Hevea brasiliensis Muell. Arg.) e em monocultivo," in Proceedings of the Anais do VI Congresso Brasileiro de Sistemas Agroflorestais, Campos, Brazil, 2006.

[47] G. Schroth, J. Lehmann, M. R. L. Rodrigues, E. Barros, and J. L. V. Macêdo, "Plant-soil interactions in multistrata agroforestry in the humid tropics," Agroforestry Systems, vol. 53, no. 2, pp. 85-102, 2001.

[48] P. M. Vitousek, K. Cassman, C. Cleveland et al., "Towards an ecological understanding of biological nitrogen fixation," Biogeochemistry, vol. 57-58, pp. 1-45, 2002.

[49] S. Mochiutti and J. A. L. Queiroz, "Aporte de nutrientes ao solo via serrapilheira em pousios florestais com taxi-branco e capoeira no Amapá," in Anais do VI Congresso Brasileiro de Sistemas Agroflorestais, Campos, Brazil, 2006.

[50] H. Kreibich, J. Lehmann, G. Scheufele, and J. Kern, "Nitrogen availability and leaching during the terrestrial phase in a várzea forest of the Central Amazon floodplain," Biology and Fertility of Soils, vol. 39, no. 1, pp. 62-64, 2003.

[51] C. Pye-Smith, Farming trees, banishing hunger. How an agroforestry programme is helping smallholders in Malawi to grow more food and improve their livelihoods, World Agroforestry Centre, Nairobi, Kenya, 2008.

[52] G. Sileshi, F. K. Akinnifesi, O. C. Ajayi, and F. Place, Evidence for impact of green fertilizers on maize production in sub-Saharan Africa: a meta-analysis, ICRAF Occasional Paper No. 10, World Agroforestry Centre, Nairobi, Kenya, 2009.

[53] F. A. De Alcântara, A. E. Furtini Neto, M. B. De Paula, H. A. De Mesquita, and J. A. Muniz, "Green manuring in the recovery of degraded oxisoil fertility," Pesquisa Agropecuaria Brasileira, vol. 35, no. 2, pp. 277-288, 2000.

[54] L. R. Queiroz, F. C. Coelho, D. G. Barroso, and V. A. V. Queiroz, "Evaluation of phytomass productivity and N, P and $\mathrm{K}$ accumulation of shrub legumes in alley cropping system in Campos dos Goytacazes (RJ)," Revista Arvore, vol. 31, no. 3, pp. 383-390, 2007.

[55] E. A. Delarmelinda, F. A. R. Sampaio, J. R. M. Dias, L. B. Tavella, and J. S. de Silva, "Green manure and changes on chemical characteristics of a soil in the Ji-Paraná-RO region," Acta Amazonica, vol. 40, no. 3, pp. 625-628, 2010.

[56] E. G. Neves, J. B. Petersen, R. N. Bartone, and C. A. Silva, "Historical and socio-cultural origins of Amazonian dark earths," in Amazonian Dark Earths: Origin, Properties, Management, J. Lehmann, D. Kern, and B. Glaser, Eds., pp. 2950, Kluwer Academic Publishers, 2003.

[57] C. L. Bergo, E. P. Pacheco, H. A. De Mendonça, and J. T. D. S. Marinho, "Evaluation of legume species for coffee plants formation in the segment of family farms in Acre," Acta Amazonica, vol. 36, no. 1, pp. 19-24, 2006.

[58] L. V. C. Gonçalves, F. G. B. Barreto, L. C. G. Gomes, E. M. G. Duarte, and I. M. C. Cardoso, "Contribuições de árvores nativas da Mata Atlântica para a ciclagem de nutrientes em sistemas agroflorestais," in Anais do Simpósio Mineiro de Ciência do Solo, Viçosa, Brazil, 2010.

[59] D. A. Posey, "Manejo da floresta secundária, capoeiras, campos e cerrados (Kayapó)," in Suma Etnológica Brasileira, pp. 173-185, FINEP, 1987.

[60] B. G. Ribeiro, "Classificação dos solos e horticultura Desâna," in 1st International Congress of Ethnobiology, vol. 2, pp. 27-49, Belém, Brazil, 1990.

[61] R. P. Miller and P. K. R. Nair, "Indigenous agroforestry systems in Amazonia: from prehistory to today," Agroforestry Systems, vol. 66, no. 2, pp. 151-164, 2006.

[62] C. R. Clement, "1492 and the loss of amazonian crop genetic resources. I. The relation between domestication and human population decline," Economic Botany, vol. 53, no. 2, pp. 188202, 1999.

[63] D. W. Lathrap, "Our father the cayman, our mother the gourd: Spinden revisited, or a unitary model for the emergence of agriculture in the New World," in Origins of Agriculture, pp. 713-751, Mouton, The Hague, The Netherlands, 1977.

[64] R. P. Miller, J. W. Penn, and J. Leeuwen, "Amazonian homegardens: their ethnohistory and potential contribution to agroforestry development," in Tropical Homegardens: A TimeTested Example of Sustainable Agroforestry, B. M. Kumar and P. K. R. Nair, Eds., pp. 43-60, Springer, 2006.

[65] C. Erickson, "Historical ecology and future explorations," in Amazonian Dark Earths: Origin, Properties, Management, J. Lehmann, D. Kern, and B. Glaser, Eds., pp. 455-500, Kluwer Academic Publishers, Dodrecht, The Netherlands, 2003.

[66] B. Glaser, W. Zech, and W. I. Woods, "History, current knowledge and future perspectives of geoecological research concerning the origin of Amazonian anthropogenic dark earths (Terra Preta)," in Exploration in Amazonian Dark Earths, B. Glaser and W. I. Woods, Eds., pp. 9-17, Springer, Berlin, Germany, 2004.

[67] A. B. Junqueira, G. H. Shepard, and C. R. Clement, "Secondary Forests on Anthropogenic Soils of the Middle Madeira River: Valuation, Local Knowledge, and Landscape Domestication in Brazilian Amazonia," Economic Botany, vol. 65, no. 1, pp. 8599, 2011.

[68] B. M. Kumar, S. J. George, and S. Chinnamani, "Diversity, structure and standing stock of wood in the homegardens of Kerala in peninsular India," Agroforestry Systems, vol. 25, no. 3 , pp. 243-262, 1994.

[69] R. M. B. Lima, Descrição, Composição e Manejo dos Cultivos Mistos de Quintal naVárzea da "Costa do Caldeirão", M.S. dissertation, INPA/UFAM, Manaus, Brazil, 1994.

[70] E. Brocki, Sistemas agroflorestais de cultivo e pousio: etnoconhecimento de agricultores familiares do lago do Paru (Manacapuru, AM), Tese de doutorado, INPA/UA, Manaus, Brazil, 2001.

[71] W. M. Denevan, "Semi-intensive pre-european cultivation and the origins of anthropogenic dark earths in Amazonia," in Exploration in Amazonian Dark Earths, B. Glaser and W. I. Woods, Eds., pp. 135-143, Springer, Berlin, Germany, 2004.

[72] A. Peyre, A. Guidal, K. F. Wiersum, and F. Bongers, "Dynamics of homegarden structure and function in Kerala, India," Agroforestry Systems, vol. 66, no. 2, pp. 101-115, 2006. 
[73] R. C. Pinho, Quintais agroflorestais indígenas em área de savana (Lavrado) na Terra Indígena Araçá, Roraima, dissertation, INPA/UFAM, Manaus, Brazil, 2008.

[74] R. C. Pinho, L. D. Magalhães, R. P. Miller, K. Uguen, and S. S. Alfaia, "Description of homegardens in Araçá Indigenous Land, in the Lavrado (savannas) of Roraima, Brazil," in 2nd World Congress of Agroforestry, Nairobi, Kenya, 2009.

[75] R. C. Pinho, S. S. Alfaia, R. P. Miller et al., "Islands of fertility: soil improvement under indigenous homegardens in the savannas of Roraima, Brazil," Agroforestry Systems, vol. 81, no. 3, pp. 235-247, 2011.

[76] J. F. Vale Júnior and M. I. L. Souza, "Caracterização e distribuição dos solos das savanas de Roraima," in Savanas de Roraima: Etnoecologia, Biodiversidade e Potencialidades Agrossilvipastoris, R. I. Barbosa, H. A. M. Xaud, and J. M. Costa e Sousa, Eds., pp. 79-92, FEMACT, Boa Vista, Brazil, 2005.

[77] V. M. B. Freitas, Dinâmica do nitrogênio em capoeiras e florestas em savanas de Roraima, M.S. dissertation, Instituto Nacional de Pesquisas da Amazônia, Manaus, Brazil, 2008.

[78] A. E. S. Soares, Nutrientes e Carbono no Solo em Áreas com diferentes Sistemas de Uso na Região do Alto Solimões (Benjamin Constant AM), M.S. dissertation, Instituto Nacional de Pesquisas da Amazônia, 2006.

[79] J. L. Vivan, Agricultura e Florestas: Princípios de uma Integração Vital, Agropecuária, Guaíba, Brazil, 1998.

[80] Empresa Brasileira de Pesquisa Agropecuária-Embrapa and Instituto Nacional de Pesquisas Espaciais-INPE, Levantamento de informações de uso e cobertura da terra na Amazônia, Sumário Executivo, Brasilia, Brazil, 2011.

[81] F. M. M. Magalhães, L. M. S. Magalhães, L. A. Oliveira, and J. Dobereiner, "Ocorrência de nodulação em leguminosas florestais de terra firme nativas da região de Manaus-AM," Acta Amazonica, vol. 12, no. 3, pp. 509-514, 1982.

[82] L. A. G. Souza, M. F. Silva, and F. W. Moreira, "Capacidade de nodulação de cem leguminosas da Amazônia," Acta Amazonica, vol. 24, no. 1-2, pp. 9-18, 1994.

[83] C. M. S. De Andrade, J. F. Valentim, and J. D. C. Carneiro, "Baginha trees (Stryphnodendron guianense (Aubl.) Benth.) in cultivated pasture ecosystems in the Western Amazon," Revista Brasileira de Zootecnia, vol. 31, no. 2, pp. 574-582, 2002.

[84] A. M. N. Izac, "Economic aspects of soil fertility management and agroforestry practices," in Trees, Crops and Soil Fertility, G. Schroth and F. L. Sinclair, Eds., pp. 13-37, CAB International, 2003. 

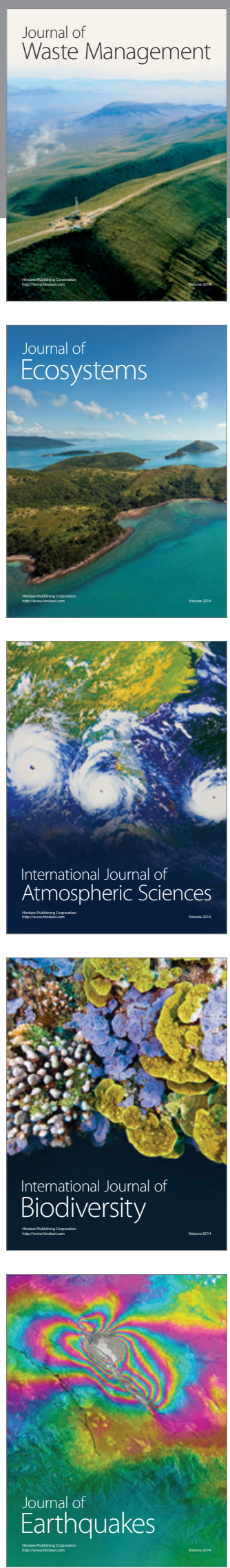
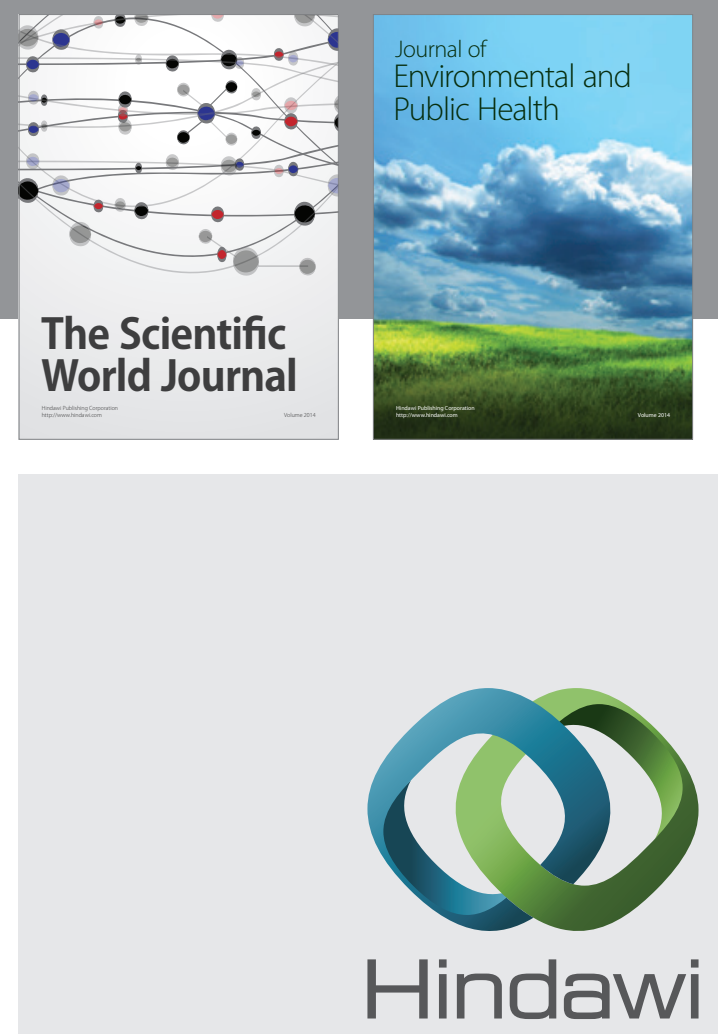

Submit your manuscripts at

http://www.hindawi.com
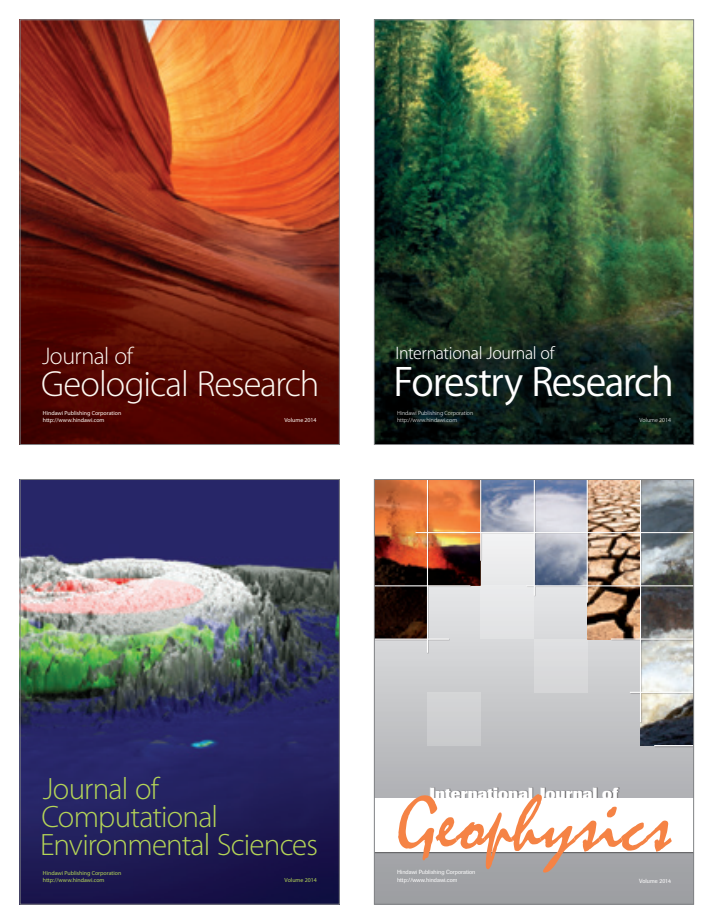
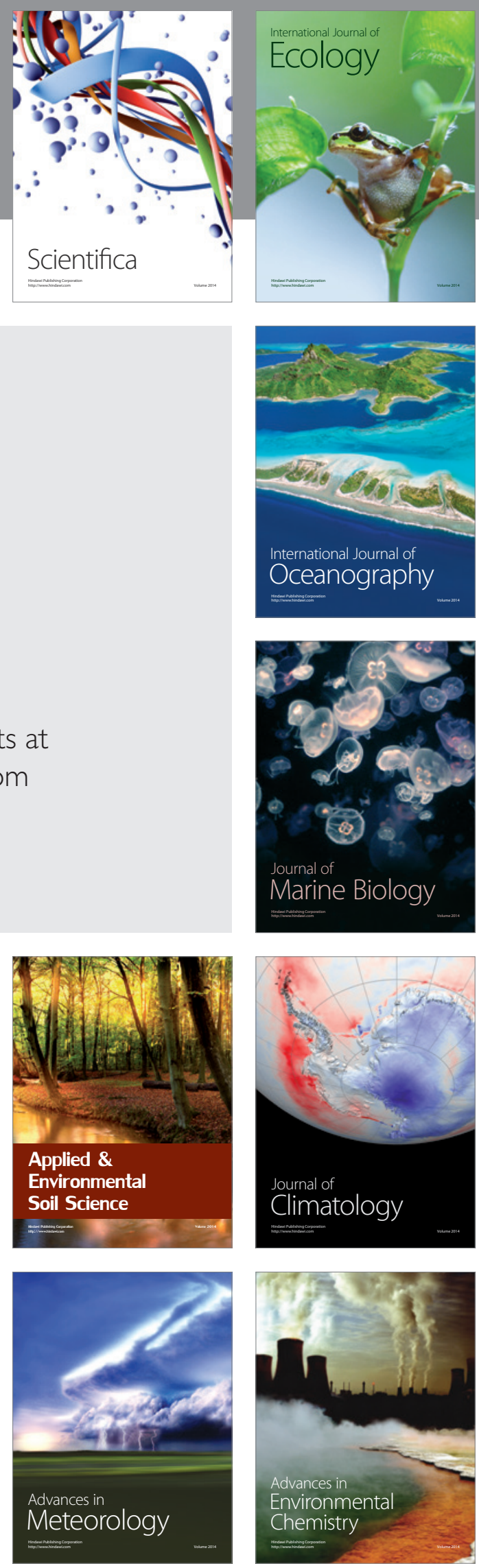